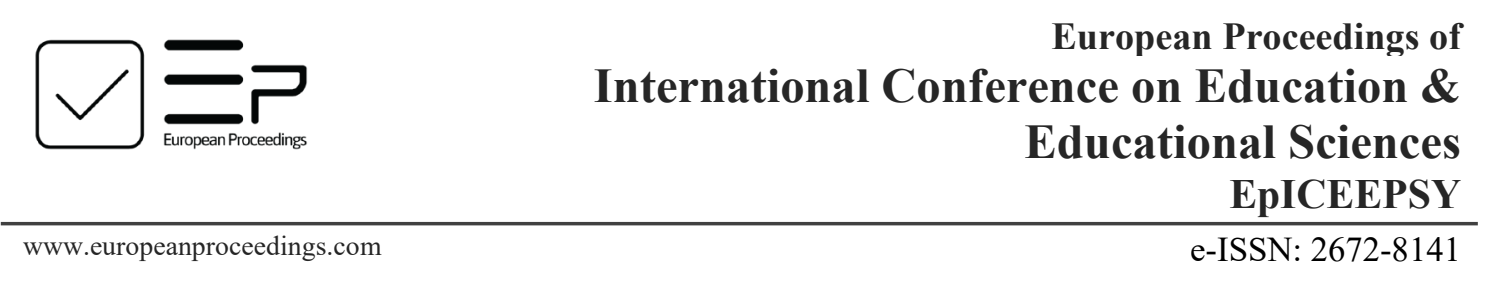

DOI: $10.15405 /$ epiceepsy.20111.3

$11^{\text {th }}$ ICEEPSY 2020

The International Conference on Education and Educational Psychology

\title{
VALUABLE ORIENTATIONS AS FACTOR OF FAMILY SELF- DETERMINATION DEVELOPMENT OF MODERN STUDENTS
}

\author{
Svetlana Vasilyevna Merzlyakova (a)*, Marina Gerasimovna Golubeva (b) \\ *Corresponding author \\ (a) Astrakhan State University, Chair of General and Cognitive Psychology, Tatishcheva St. 20a, Astrakhan, Russia, \\ svetym@yandex.ru \\ (b) Astrakhan State University, Chair of English Language for Humanitarian Specialties, Tatishcheva St. 20a, \\ Astrakhan, Russia, marinaGZH@yandex.ru
}

\begin{abstract}
Theoretical and empirical researches of components of structure, content characteristics, types and determinants of family self-determination of modern youth have only recently begun to appear in developmental psychology. Valuable orientations as a factor influencing the process of family selfdetermination of students have not been studied enough. Research objective is to identify features of family self-determination of student's youth depending on the structure of valuable orientations at different stages of age development: youthful age (from 17 to 19 years), early adulthood (from 20 to 22 years). 1086 students of Astrakhan State University, Astrakhan Branch of Russian Academy of National Economy and Public Administration under the President of Russian Federation participated in this research. Depending on the structure of valuable orientations, using divisive clustering of the empirical sample, we divided all respondents into three homogeneous clusters: 1) orientation on the values of professional self-realization (193 respondents, $17.8 \%$ ); 2) orientation on gnostic and aesthetic values (274 respondents, 25.2\%); 3) orientation on the values of personal life (619 respondents, 57\%). The structure of valuable orientations is an important factor determining the process of family self-determination of student's youth. Valuable orientations have an equal impact on the development of cognitive and motivational components of students ' family self-determination. The structure of valuable orientations largely determines the features of the development of value-emotional, reflexive, and regulatory-behavioral components of family selfdetermination in adolescence compared to early adulthood.
\end{abstract}

2672-8141 (c) 2020 Published by European Publisher.

Keywords: Family self-determination, valuable orientations, student's youth. 
https://doi.org/10.15405/epiceepsy.20111.3

Corresponding Author: Svetlana Vasilyevna Merzlyakova

Selection and peer-review under responsibility of the Organizing Committee of the conference

2672-8141

\section{Introduction}

The intensive socio-economic and political transformations have a significant impact on personal development in modern world. The influence of information environment in general, media culture, online communities, and electronic mass media is increasing in various types of activity and ways of communication on the process of socialization at teenage and adolescence. Formation of personal and social self-determination of modern youth takes place in the conditions of ideological uncertainty, multiculturalism, and the coexistence of essentially different values' systems with multiple limits of acceptable behavior. A necessary condition for personal self-determination is the formation of one's own system of valuable orientations. The formation problem of valuable orientations' structure of modern youth and the search for socio-psychological determinants of productive values' development is relevant in Russia (Podolskiy \& Idobaeva, 2019), China (Danilenko et al., 2017), Bulgaria (Garvanova \& Papazova, 2017), Turkey (Vartanova \& Karaca, 2016) and other countries.

We have analysed approaches of some scientists to definition of the concept "valuable orientations" (I.I. Vartanova, N. M. Lebedeva, A. N. Tatarko, A. N. Alekhin, N.N. Koroleva, E.I. Ostasheva, etc.) and we took the definition proposed by Zhuravleva (2015), from whose point of view, valuable orientations are " relatively stable, socially caused orientation of the individual towards certain goals with meaningful life value, and on the certain ways of their achievement as any personal qualities, examples (ways) of behavior and being rather independent of personal situations" as a basis of our research (p. 52). Vartanova (2014) notes that the system of valuable orientations determines the content side of the life perspective as a system of adaptations and means of assimilation of inner world, providing a higher type of behavioral regulation. The obtained data from the study of high school students (grades 9 and 11) allowed us to conclude that the significance and availability of the analyzed value groups are largely determined by the dominant motivation and gender of high school students (Vartanova, 2014). In this regard, Vartanova (2014) considers correlation between already existing motives and the assimilated valuable orientations (defining a zone of the closest development of motives) as one of mechanisms of personal growth and development. Boys and girls of identical age with expressiveness of the same motivation have significantly different values' systems (Vartanova, 2016). Girls see the possibility of self-realization at school through knowledge process (value "self-improvement in education"), and in the future in the implementation of family relationships (value «happy family life"). In older adolescence, boys self-actualize in the status-competitive and affiliation areas (values "recognition in the team", "my authority"). The hierarchy of values and selfrelations of senior teenagers and young men towards age aspect were compared (Podolskiy \& Idobaeva, 2019). When comparing the value system of youth in the 1990s and 2000s, the authors note a decrease in the orientation of modern boys and girls towards achievement, personal success, and an increase in valuable orientation towards welfare of other people and society. At the same time the process of identity formation with modern youth is complicated: weak differentiation of motivational goals, their conflict in the semantic sphere indicate the endured crisis, and the existence of "painful points" in the self-consciousness of adolescents and young men. The interrelation of valuable orientations and features of ethnic and cultural identity of Armenian and Russian students (Berberyan \& Berberyan, 2017), a component of religious identity of high school students of the Buddhist religion (Shorokhova et al., 2016) is revealed. The values 
motivating on achievement of personal success and manifestation of independence, on care of welfare of close people are the center of valuable consciousness of modern Russian students (Danilenko et al., 2017).

Valuable orientations are of great importance for predicting people's behavior. Lebedeva and Tatarko (2018) revealed the interrelation between valuable orientations and predisposition to economic behavior. It is established that specific values cannot always be considered as universal predictors of economic behavior in different religious confessions. When considering the interrelation between values, economic attitudes, and behavior, it is necessary to take into account the socio-cultural characteristics of groups. The religious aspect plays a significant differentiating role in the choice of models of economic behavior. The values of Orthodox Christians indicate the low importance of money in comparison with other resources - creativity, time, etc. On the contrary the values of Muslims encourage them to support economic activity, independence, and rationality in financial behavior. Zhuravleva (2015) considers valuable orientations as a psychological factor of business and administrative activity. An empirical research by Arina et al. (2018) showed that explicit (conscious) and implicit (unconscious) values are associated with decision-making in health-related situations. It has been established that in situations with high potential losses decision-making to the detriment of health at adolescence is connected not so much with low importance of values of health and safety, as with high importance of values of independence, kindness and achievements.

Alekhin et al. (2015) consider values as a predictor of social disadaptation and deviant behavior among modern adolescents. Adolescents with deviant behavior (alcohol and drug use, risky sexual behavior, autoagression) support anti-social values. In the context of disharmonious relationships in the parental family (aggression, family violence, distrust, emotional rejection, etc.), adolescents form a fragmented and contradictory image of the world, short-term and unstable relationships with the opposite sex, adults and peers.

Semenova et al. (2018) established the dependence of parenting motivation on the system of personal valuable orientations at the stage of early and late youth. The authors note the lack of purposeful work on the formation of stable motivation for marriage, family creation, and childbearing among modern youth, and suggest a cycle of classes focused on the development of the cognitive component of parenting motivation.

\section{Problem Statement}

Developmental psychology needs new data on current conditions and determinants of selfdetermination formation and its types among modern youth. Researchers of the structure's components, content characteristics, types, and socio-psychological factors of family self-determination of modern youth have only recently begun to appear in domestic and foreign psychology (Merzlyakova et al., 2018; Merzlyakova et al., 2019; Merzlyakova, 2019). However, the problem of correlation between the structure of values and components of family self-determination has not been studied enough. The present research is directed towards completion of this gap.

\section{Research Questions}

The following issues remain unresolved today. 
3.1. Are there any differences in the structure of valuable orientations among student's youth?

3.2. Are valuable orientations a significant factor of family self-determination development in adolescence (from 17 to 19 years) and early adulthood (from 20 to 22 years)?

\section{Purpose of the Study}

Research objective is to identify features of family self-determination of student's youth depending on the structure of valuable orientations at different stages of age development: adolescence (from 17 to 19 years), early adulthood (from 20 to 22 years). The hypothesis of this research was based on the assumption that the content and structural characteristics of family self-determination are determined by the structure of valuable orientations and age of respondents.

The research was conducted on the basis of the Astrakhan State University, the Astrakhan Branch of Russian Academy of National Economy and Public Administration under the President of Russian Federation. The study involved 1086 students. Of these, 357 are young men (32.9\%) and 729 are young women (67.1\%). We divided the entire sample into two age groups. The first group consisted of students aged 17 to 19 years -644 people (59.3\%). The second group included students aged 20 to 22 years -442 people $(40.7 \%)$.

\section{Research Methods}

5.1. For diagnostics of the structure of valuable orientations and content and structural characteristics of family self-determination, we used the questionnaire "A Value and Availability Ratio in Various Vital Spheres Technique" by Fantalova (2001), the method of Semantic Differential, projective technique of "Incomplete Sentences», “A Purpose-in-Life Test” by Leontyev (2000), the questionnaire "Role expectations and claims in marriage" by Volkova and Trapeznikova (1985).

5.2. During the analytical stage we used mathematical and statistical data processing methods that allowed us to establish the reliability of the research results. All calculations were performed using the IBM SPSS Statistics 21 computer program. The analysis included descriptive statistics, the KolmogorovSmirnov test for one sample, Levene's Test for Equality of Variances, one-way ANOVA on ranks for independent samples, the Kruskal-Wallis test by ranks, and cluster analysis (the K-means method).

\section{Findings}

\subsection{Identification of differences in the structure of valuable orientations among student's youth}

We determined the hierarchy of values of student's youth at the first stage of our research using the questionnaire "A Value and Availability Ratio in Various Vital Spheres Technique" by Fantalova (2001). We divided all respondents into three homogeneous clusters as a result of divisive clustering of the empirical sample. Fischer's F-test revealed the significance of differences in the average values of variables across clusters (table 1). The first cluster includes students (193 people, $17.8 \%$ ), for whom the values of active life, interesting work, financially secure life, self-confidence, freedom as independence in acts and actions are important. Let's call this cluster "orientation towards values of professional self-realization". The second cluster was made up of students (274 people, $25.2 \%$ ), who differ in the significance of such 
values as knowledge, creativity, beauty of nature and art. Let's define the second cluster as "orientation towards gnostic and aesthetic values". The third cluster includes students (619 people, $57 \%$ ), for whom a happy family life, love, health, and having good and loyal friends are highly significant. The third cluster is designated as "orientation towards values of personal life".

Table 01. Results of divisive clustering of an empirical sample (method K average)

\begin{tabular}{|c|c|c|c|c|c|}
\hline \multirow[t]{2}{*}{ Values } & \multicolumn{3}{|c|}{ Final centers of clusters } & \multirow{2}{*}{$\begin{array}{l}\text { Value } \\
\text { F - criterion }\end{array}$} & \multirow{2}{*}{$\begin{array}{l}\text { Significance } \\
\text { value }\end{array}$} \\
\hline & 1 & 2 & 3 & & \\
\hline Active deedful life & 4.79 & 3.45 & 3.67 & 30.814 & 0.000 \\
\hline Health (physical and mental health) & 7.03 & 5.03 & 7.84 & 105.229 & 0.000 \\
\hline Interesting work & 5.80 & 4.43 & 4.76 & 29.141 & 0.000 \\
\hline Beauty of nature and art & 3.10 & 3.96 & 1.76 & 121.298 & 0.000 \\
\hline $\begin{array}{l}\text { Love (spiritual and physical intimacy } \\
\text { with a loved one) }\end{array}$ & 3.97 & 6.41 & 8.17 & 269.594 & 0.000 \\
\hline $\begin{array}{l}\text { Financially secure life (lack of } \\
\text { material difficulties) }\end{array}$ & 7.22 & 3.74 & 6.21 & 143.539 & 0.000 \\
\hline Presence of good and loyal friends & 6.33 & 5.61 & 6.79 & 21.834 & 0.000 \\
\hline $\begin{array}{l}\text { Self-confidence (freedom from } \\
\text { internal contradictions, doubts) }\end{array}$ & 6.54 & 5.72 & 5.68 & 13.235 & 0.000 \\
\hline $\begin{array}{l}\text { Knowledge (possibility of expansion } \\
\text { of his/her education, outlook, general } \\
\text { culture and also intellectual } \\
\text { development) }\end{array}$ & 5.78 & 6.12 & 3.99 & 93.266 & 0.000 \\
\hline $\begin{array}{l}\text { Freedom as independence in acts and } \\
\text { actions }\end{array}$ & 6.80 & 5.91 & 5.11 & 35.289 & 0.000 \\
\hline Happy family life & 4.41 & 8.37 & 9.95 & 625.827 & 0.000 \\
\hline $\begin{array}{l}\text { Creativity (possibility of creative } \\
\text { activity) }\end{array}$ & 3.67 & 6.47 & 1.64 & 535.407 & 0.000 \\
\hline
\end{tabular}

\subsection{The research of the relationship between valuable orientations and family self- determination in adolescence and early adulthood}

Using a single-factor variance analysis for independent samples (F) and the nonparametric KruskalWallis test $(\mathrm{H})$ we evaluated the validity of differences in the content-structural characteristics of family self-determination in adolescence and early adulthood. There were found such differences for the variables "I am a future husband / wife, I am a future father / mother, I am a host / hostess, I am a son / daughter" at the level of statistical significance in the cognitive component of family self-determination, depending on the structure of valuable orientations (table 2). The median values indicate that family roles are more important in adolescence for students who are focused on personal life values. For students who are focused on the values of professional self-realization, these family roles are the least important. A similar trend is observed in early adulthood. Family roles "I am a future husband / wife, I am a future father / mother, I am a host / hostess, I am a son / daughter" are the most important for respondents focused on the values of personal life, and the least important for students with a focus on professional self-realization. 
Table 02. Assessment of the differences' reliability in indicators of the cognitive component of family selfdetermination depending on the structure of students ' valuable orientations

\begin{tabular}{|c|c|c|c|c|c|}
\hline \multirow{2}{*}{$\begin{array}{l}\text { Structural and content characteristics of } \\
\text { family self-determination }\end{array}$} & \multicolumn{3}{|c|}{ Value of a median } & \multirow[b]{2}{*}{ 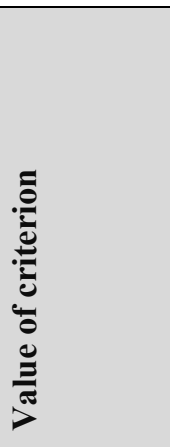 } & \multirow[b]{2}{*}{ 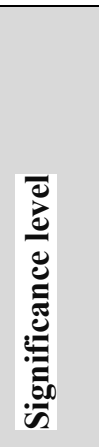 } \\
\hline & 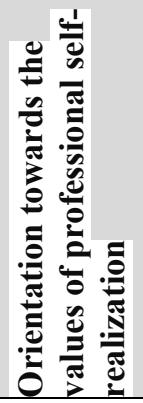 & 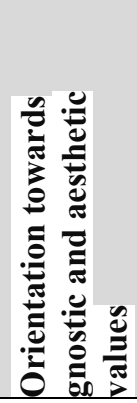 & 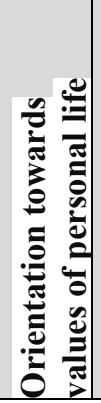 & & \\
\hline \multicolumn{6}{|l|}{ Adolescence (from 17 to 19 years) } \\
\hline I am a future husband/I am a future wife & 5.17 & 5.83 & 6.33 & $\mathrm{H}=67.277$ & 0.000 \\
\hline I am a future father/I am a future mother & 5.58 & 6 & 6.5 & $\mathrm{H}=58.367$ & 0.000 \\
\hline I am a host / I am a hostess & 5 & 5.33 & 5.67 & $\mathrm{H}=17.469$ & 0.000 \\
\hline I am a daughter/ I am a son & 5.17 & 5.5 & 6 & $\mathrm{H}=22.826$ & 0.000 \\
\hline \multicolumn{6}{|l|}{ Early adulthood (from 20 to 22 years) } \\
\hline I am a future husband/I am a future wife & 5.08 & 6 & 6.5 & $\mathrm{H}=57.219$ & 0.000 \\
\hline I am a future father/I am a future mother & 5.08 & 6.17 & 6.67 & $\mathrm{H}=54.364$ & 0.000 \\
\hline I am a host / I am a hostess & 5.17 & 5.33 & 5.83 & $\mathrm{H}=28.674$ & 0.000 \\
\hline I am a daughter/ I am a son & 5.08 & 5.17 & 5.83 & $\mathrm{H}=23.676$ & 0.000 \\
\hline
\end{tabular}

In adolescence the structure of value orientations determines the features of almost all elements of the value-emotional component of students' family self-determination (table 03). The respondents focused on the values of personal life, different importance of the parental family, marriage, relationship with mother and father and value family life. They are characterized by a more positive attitude towards family as a social institution, towards their own family, towards position of the individual in the family structure, towards future marriage partner, towards themselves, towards future children, towards love of romantic type, towards family recreation and leisure, towards parental family and mother. Students are characterized by purposefulness, perception of life as interesting and emotionally rich, satisfaction with self-realization, meaningfulness of life. Students who are focused on gnostic and aesthetic values have a positive attitude towards their own family, towards the position of the individual in the family structure, towards future marriage partner, towards themselves, towards future children, towards love of romantic type, towards sex, towards family recreation and leisure, towards parental family, towards mother. In early adulthood, valuable orientations to a lesser extent determine the features of the development of the value-emotional component of family self-determination in comparison with adolescence. Students focused on the values of personal life are characterized by high importance of the parental family, marriage, relationships with mother and father, their future family, a positive attitude towards family as a whole, future marriage partner, themselves, future children, sex, commitment, satisfaction with self-realization, a high indicator of meaningfulness of life. Students who focus on gnostic and aesthetic values are characterized by a positive attitude towards future marriage partner, themselves, future children, sex, and commitment. 
Table 03. Assessment of the differences' reliability in indicators of the valuable and emotional component of family self-determination depending on the structure of students' valuable orientations

\begin{tabular}{|c|c|c|c|c|c|}
\hline \multirow{2}{*}{$\begin{array}{l}\text { Structural and content characteristics of } \\
\text { family self-determination }\end{array}$} & \multicolumn{3}{|c|}{ Value of a median } & \multirow[b]{2}{*}{ 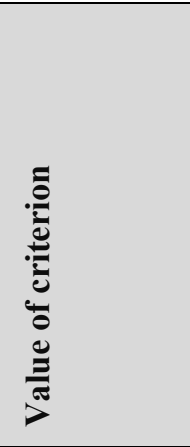 } & \multirow[b]{2}{*}{ 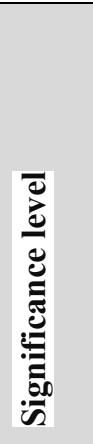 } \\
\hline & 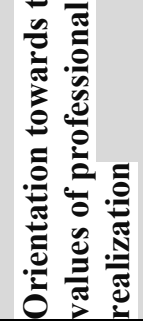 & 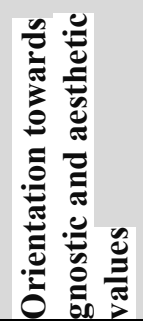 & 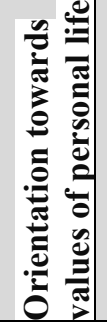 & & \\
\hline \multicolumn{6}{|c|}{ Adolescence (from 17 to 19 years) } \\
\hline Parental family & 5.83 & 6.17 & 6.33 & $\mathrm{H}=14.543$ & 0.001 \\
\hline Marriage & 5.17 & 5.83 & 6.33 & $\mathrm{H}=61.38$ & 0.000 \\
\hline My mother & 6.5 & 6.5 & 6.83 & $\mathrm{H}=14.67$ & 0.001 \\
\hline My father & 5.17 & 5.33 & 6 & $\mathrm{H}=17.86$ & 0.000 \\
\hline My future family & 6 & 6.33 & 6.83 & $\mathrm{H}=45.57$ & 0.000 \\
\hline Attitude towards family & 4 & 4 & 5 & $\mathrm{H}=9.036$ & 0.011 \\
\hline We are a family ( attitude towards own family) & 3 & 4 & 4 & $\mathrm{H}=19.939$ & 0.000 \\
\hline $\begin{array}{l}\text { Position of the personality in the family's } \\
\text { structure }\end{array}$ & 3 & 4 & 4 & $\mathrm{H}=8.85$ & 0.012 \\
\hline Attitude towards future marriage partner & 3 & 4 & 4 & $\mathrm{H}=9.377$ & 0.009 \\
\hline Attitude towards themselves & 2 & 3 & 3 & $\mathrm{H}=9.983$ & 0.007 \\
\hline Attitude towards future children & 3 & 4 & 4 & $\mathrm{H}=8.417$ & 0.015 \\
\hline Attitude towards love of romantic type & 3 & 4 & 4 & $\mathrm{H}=10.730$ & 0.005 \\
\hline Attitude toward sex & 2 & 3 & 2 & $\mathrm{H}=8.450$ & 0.015 \\
\hline Attitude towards family recreation, leisure & 3 & 4 & 4 & $\mathrm{H}=8.016$ & 0.018 \\
\hline Attitude towards parental family & 3 & 4 & 4 & $\mathrm{H}=7.441$ & 0.024 \\
\hline Attitude towards mother & 3 & 4 & 4 & $\mathrm{H}=11.269$ & 0.004 \\
\hline Attitude towards father & 2 & 3 & 3 & $\mathrm{H}=4.331$ & 0.115 \\
\hline Purposes in life & 31 & 31 & 33 & $\mathrm{H}=15.107$ & 0.001 \\
\hline Process of life & 29 & 29 & 31 & $\mathrm{H}=8.956$ & 0.011 \\
\hline Effectiveness of life & 26 & 25 & 27 & $\mathrm{H}=13.603$ & 0.001 \\
\hline General indicator of meaningfulness of life & 101 & 99 & 105 & $\mathrm{H}=13.554$ & 0.001 \\
\hline \multicolumn{6}{|c|}{ Early adulthood (from 20 to 22 years) } \\
\hline Parental family & 5.67 & 5.67 & 6.17 & $\mathrm{H}=21.677$ & 0.000 \\
\hline Marriage & 4.83 & 5.67 & 6.33 & $\mathrm{H}=49.234$ & 0.000 \\
\hline My mother & 6.08 & 6.17 & 6.67 & $\mathrm{H}=17.219$ & 0.000 \\
\hline My father & 5.25 & 5.33 & 5.67 & $\mathrm{H}=8.005$ & 0.018 \\
\hline My future family & 5.58 & 6 & 6.67 & $\mathrm{H}=49.287$ & 0.000 \\
\hline Attitude towards family & 4 & 4 & 5 & $\mathrm{H}=11.524$ & 0.003 \\
\hline We are a family ( attitude towards own family) & 3.5 & 4 & 4 & $\mathrm{H}=5.914$ & 0.052 \\
\hline $\begin{array}{l}\text { Position of the personality in the family's } \\
\text { structure }\end{array}$ & 3 & 3 & 3 & $\mathrm{H}=2.781$ & 0.249 \\
\hline Attitude towards future marriage partner & 3 & 4 & 4 & $\mathrm{H}=12.289$ & 0.002 \\
\hline Attitude towards themselves & 1.5 & 2 & 2 & $\mathrm{H}=7.039$ & 0.030 \\
\hline Attitude towards future children & 2.5 & 4 & 4 & $\mathrm{H}=14.798$ & 0.001 \\
\hline Attitude towards love of romantic type & 3 & 3 & 4 & $\mathrm{H}=5.434$ & 0.066 \\
\hline Attitude toward sex & 1 & 2 & 2 & $\mathrm{H}=9.780$ & 0.008 \\
\hline Attitude towards family recreation, leisure & 3 & 4 & 4 & $\mathrm{H}=3.980$ & 0.137 \\
\hline Attitude towards parental family & 3 & 3 & 3 & $\mathrm{H}=2.639$ & 0.267 \\
\hline
\end{tabular}


Selection and peer-review under responsibility of the Organizing Committee of the conference

$2672-8141$

\begin{tabular}{|l|l|l|l|l|l|}
\hline Attitude towards mother & 4 & 4 & 4 & $\mathrm{H}=0.207$ & 0.902 \\
\hline Attitude towards father & 2 & 3 & 2 & $\mathrm{H}=0.004$ & 0.998 \\
\hline Purposes in life & 30 & 34 & 34 & $\mathrm{H}=15.407$ & 0.000 \\
\hline Process of life & 28.5 & 30 & 30 & $\mathrm{~F}=1.974$ & 0.140 \\
\hline Effectiveness of life & 24 & 27 & 28 & $\mathrm{H}=22.275$ & 0.000 \\
\hline General indicator of meaningfulness of life & 98 & 105.5 & 107 & $\mathrm{H}=11.706$ & 0.003 \\
\hline
\end{tabular}

Valuable orientations determine the development of indicators of the regulatory and behavioral component of family self-determination in adolescence and early adulthood (table. 04). In adolescence valuable orientations determine the development of ideas about the time perspective, means of achieving goals, and role expectations. Students who are focused on the values of their personal life appreciate the past, present and future. They are characterized by the availability of the sphere of happy family life, a negative attitude towards divorce, conflicts in the family, the installation that the marriage partner will take on the role of an emotional leader in their family and provide moral and emotional support to its members. Students who focus on gnostic and aesthetic values are characterized by the availability of knowledge and creativity. They will more often use educational and creative opportunities as a means to achieve their goals. They are characterized by a neutral attitude towards divorce and family conflicts. Students who are focused on the values of professional self-realization are characterized by the availability of knowledge and a negative attitude towards family conflicts. In early adulthood valuable orientations influence the formation of ideas about the present and future, the availability of such areas as a happy family life, active life, creativity, attitudes towards divorce, role expectations in the parent-educational and emotionalpsychotherapeutic spheres. Students who are focused on the values of personal life are distinguished by the significance of the present and orientation towards future, availability of a happy family life, an active life, and a negative attitude towards divorce. Students with a focus on gnostic and aesthetic values are characterized by the availability of the sphere of happy family life and creative activity, a negative attitude towards divorce, and a pronounced attitude towards the fact that the marriage partner will take an active parental position and perform an emotional and psychotherapeutic function in marriage. Students who are focused on the values of professional self-realization are available in the field of active life, but there is an extremely low availability of a happy family life.

Table 04. Assessment of differences' reliability in indicators of the regulatory and behavioural component of family self-determination depending on the structure of students ' valuable orientation

\begin{tabular}{|c|c|c|c|c|c|}
\hline \multirow{2}{*}{$\begin{array}{l}\text { Structural and content characteristics of } \\
\text { family self-determination }\end{array}$} & \multicolumn{3}{|c|}{ Value of a median } & \multirow[b]{2}{*}{ 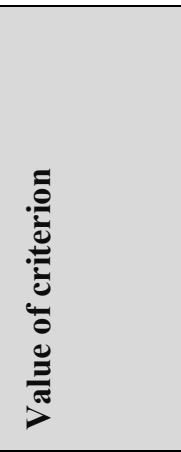 } & \multirow[b]{2}{*}{ 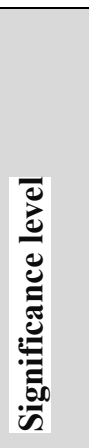 } \\
\hline & 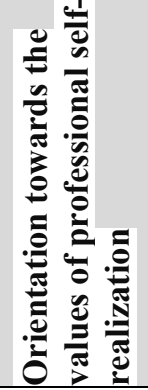 & 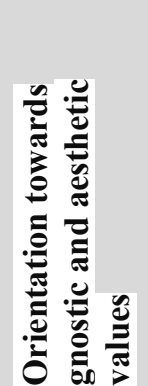 & 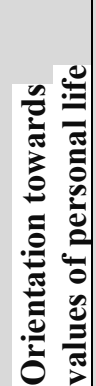 & & \\
\hline \multicolumn{6}{|c|}{ Adolescence (from 17 to 19 years) } \\
\hline My past & 4.67 & 5 & \begin{tabular}{l|l|}
5.17 \\
\end{tabular} & $\mathrm{H}=7.449$ & 0.024 \\
\hline My present & 4.83 & 5 & 5.67 & $\mathrm{H}=23.110$ & 0.000 \\
\hline
\end{tabular}




\begin{tabular}{|c|c|c|c|c|c|}
\hline My future & 5.67 & 5.67 & 6.33 & $\mathrm{H}=39.646$ & 0.000 \\
\hline Availability of the "happy family life" sphere & 4 & 5 & 6 & $\mathrm{H}=25.618$ & 0.000 \\
\hline Availability of active deedful life & 6 & 6 & 6 & $\mathrm{H}=4.616$ & 0.099 \\
\hline Availability of knowledge & 7 & 7 & 6 & $\mathrm{H}=7.449$ & 0.024 \\
\hline Availability of creativity & 5 & 6 & 4 & $\mathrm{H}=46.772$ & 0.000 \\
\hline Primacy and responsibility in the family & 4 & 4 & 4 & $\mathrm{H}=4.985$ & 0.083 \\
\hline Rights and duties of spouses & 4 & 4 & 4 & $\mathrm{H}=2.520$ & 0.284 \\
\hline Attitude towards divorce & -2 & 0 & -3 & $\mathrm{H}=14.832$ & 0.001 \\
\hline Attitude towards family conflicts & -2 & 0 & -2 & $\mathrm{H}=12.543$ & 0.002 \\
\hline Economic and household sphere (expectations) & 6 & 5 & 6 & $\mathrm{H}=1.785$ & 0.410 \\
\hline Economic and household sphere (claims) & 6 & 7 & 7 & $\mathrm{H}=0.231$ & 0.891 \\
\hline Parental and educational sphere (expectations) & 7 & 7 & 7 & $\mathrm{H}=4.364$ & 0.113 \\
\hline $\begin{array}{l}\text { Parental and educational sphere } \\
\text { (claims) }\end{array}$ & 6 & 7 & 7 & $\mathrm{H}=2.647$ & 0.266 \\
\hline Social activity (expectations) & 7 & 6 & 6 & $\mathrm{H}=2.537$ & 0.281 \\
\hline Social activity (claims) & 8 & 8 & 8 & $\mathrm{H}=0.553$ & 0.758 \\
\hline $\begin{array}{l}\text { Emotional and psychotherapeutic } \\
\text { (expectations) }\end{array}$ & 8 & 7 & 9 & $\mathrm{H}=16.512$ & 0.000 \\
\hline $\begin{array}{l}\text { Emotional and psychotherapeutic } \\
\text { (claims) }\end{array}$ & 7 & 6 & 7 & $\mathrm{H}=2.569$ & 0.277 \\
\hline Attractiveness (expectations) & 7 & 7 & 7 & $\mathrm{H}=2.912$ & 0.233 \\
\hline Attractiveness (claims) & 7 & 6 & 6 & $\mathrm{H}=1.859$ & 0.395 \\
\hline \multicolumn{6}{|c|}{ Early adulthood (from 20 to 22 years) } \\
\hline My past & 4.67 & 4.5 & 5 & $\mathrm{~F}=2.852$ & 0.059 \\
\hline My present & 5 & 5.17 & 5.67 & $\mathrm{H}=12.612$ & 0.002 \\
\hline My future & 5.18 & 5.67 & 6.33 & $\mathrm{H}=34.322$ & 0.000 \\
\hline Availability of the "happy family life" sphere & 3 & 6 & 6 & $\mathrm{H}=30.054$ & 0.000 \\
\hline Availability of active deedful life & 6 & 5.5 & 6 & $\mathrm{H}=6.173$ & 0.046 \\
\hline Availability of knowledge & 6 & 6 & 6 & $\mathrm{H}=0.540$ & 0.763 \\
\hline Availability of creativity & 4 & 6 & 4 & $\mathrm{H}=18.071$ & 0.000 \\
\hline Primacy and responsibility in the family & 4 & 4 & 4 & $\mathrm{H}=3.976$ & 0.137 \\
\hline Rights and duties of spouses & 4 & 4 & 4 & $\mathrm{H}=2.845$ & 0.241 \\
\hline Attitude towards divorce & -2 & -4 & -4 & $\mathrm{H}=18.624$ & 0.000 \\
\hline Attitude towards family conflicts & -2 & -3 & -3 & $\mathrm{H}=5.677$ & 0.059 \\
\hline Economic and household sphere (expectations) & 6 & 6 & 6 & $\mathrm{H}=1.149$ & 0.563 \\
\hline Economic and household sphere (claims) & 6 & 6 & 7 & $\mathrm{H}=4.852$ & 0.088 \\
\hline Parental and educational sphere (expectations) & 7 & 8 & 7 & $\mathrm{H}=7.003$ & 0.030 \\
\hline $\begin{array}{l}\text { Parental and educational sphere } \\
\text { (claims) }\end{array}$ & 6 & 7 & 6 & $\mathrm{H}=4.343$ & 0.114 \\
\hline Social activity (expectations) & 6 & 7 & 7 & $\mathrm{H}=5.966$ & 0.051 \\
\hline Social activity (claims) & 8 & 8 & 8 & $\mathrm{H}=1.716$ & 0.424 \\
\hline $\begin{array}{l}\text { Emotional and psychotherapeutic } \\
\text { (expectations) }\end{array}$ & 7 & 9 & 8 & $\mathrm{H}=7.616$ & 0.022 \\
\hline $\begin{array}{l}\text { Emotional and psychotherapeutic } \\
\text { (claims) }\end{array}$ & 6 & 6 & 7 & $\mathrm{H}=4.133$ & 0.127 \\
\hline Attractiveness (expectations) & 6 & 6.5 & 7 & $\mathrm{H}=0.874$ & 0.646 \\
\hline Attractiveness (claims) & 5 & 7 & 6 & $\mathrm{H}=5.389$ & 0.068 \\
\hline
\end{tabular}

Valuable orientations have an equal impact on the development of the motivational component of family self-determination in adolescence and early adulthood. From table. 05 it can be seen that there are 
significant differences for such marital motives as security, harmonious sexual relations, success, compensation for feelings of loneliness, personal independence, love, material welfare, revenge, communication with people, recognition by others, parenthood, self-actualization, happiness. In adolescence for students focused on the values of personal life, as a result of ranking the values of the medians, we received the following hierarchy of motives for marriage: 1) happiness, 2) love, 3) success, 4) harmonious sexual relations, 5) personal independence, material welfare, communication with people, 6) self-actualization, 7) security, recognition by people around, 8) parenthood. In early adulthood students in this cluster retain the content of the leading motives for marriage but their hierarchy changes: 1) love, happiness, 2) harmonious sexual relations, 3) success, 4) material welfare, self-actualization, 5) personal independence, 6) security, communication with people, recognition by people around, 7) parenthood. In adolescence students who are focused on gnostic and aesthetic values are more likely to marry out of a sense of revenge (for a former lover or for the evil of their parents). Students who are focused on the values of professional self-realization in their adolescence differ in the expression of such marital motives as personal independence, self-actualization, and compensation for feelings of loneliness. In early adulthood students of this cluster actualize such motives for marriage as the desire to avoid loneliness and revenge.

Table 05. Assessment of differences' reliability in indicators of the motivational component of family selfdetermination depending on the structure of students ' valuable orientations

\begin{tabular}{|c|c|c|c|c|c|}
\hline \multirow{2}{*}{$\begin{array}{l}\text { Structural and content characteristics of } \\
\text { family self-determination }\end{array}$} & \multicolumn{3}{|c|}{ Value of a median } & \multirow[b]{2}{*}{ 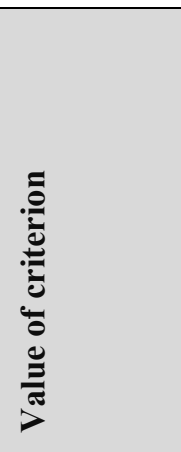 } & \multirow[b]{2}{*}{ 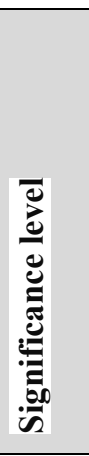 } \\
\hline & 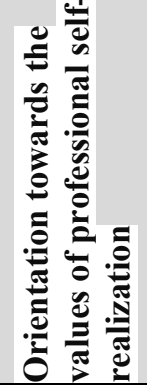 & 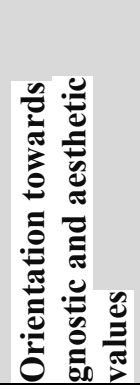 & 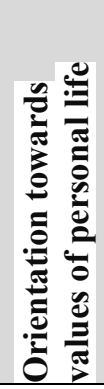 & & \\
\hline \multicolumn{6}{|l|}{ Adolescence (from 17 to 19 years) } \\
\hline Security & 5.17 & 5 & 5.5 & $\mathrm{H}=8.676$ & 0.013 \\
\hline Harmonious sexual relations & 5 & 5.33 & 6 & $\mathrm{H}=31.633$ & 0.000 \\
\hline Duty & 4 & 4 & 4 & $\mathrm{H}=5.283$ & 0.071 \\
\hline Achievement of success & 6 & 5.83 & 6.17 & $\mathrm{H}=11.335$ & 0.003 \\
\hline Compensation for feeling of loneliness & 3.83 & 3.5 & 2.67 & $\mathrm{H}=31.140$ & 0.000 \\
\hline Personal independence ("escape from parents") & 5.83 & 5.08 & 5.83 & $\mathrm{H}=15.606$ & 0.000 \\
\hline Love & 5.33 & 6.17 & 6.67 & $\mathrm{H}=55.259$ & 0.000 \\
\hline Material welfare & 5.5 & 5.17 & 5.83 & $\mathrm{H}=18.916$ & 0.000 \\
\hline Revenge & 3.42 & 3.67 & 2.83 & $\mathrm{H}=9.594$ & 0.008 \\
\hline Communication with people & 5.33 & 5.33 & 5.83 & $\mathrm{H}=20.243$ & 0.000 \\
\hline Recognition by people around & 5 & 5 & 5.5 & $\mathrm{H}=10.839$ & 0.004 \\
\hline Parenthood & 4.67 & 4.67 & 5.17 & $\mathrm{H}=37.329$ & 0.000 \\
\hline Self-actualization & 5.67 & 5.5 & 5.67 & $\mathrm{H}=13.252$ & 0.001 \\
\hline Happiness & 6.33 & 6.5 & 6.83 & $\mathrm{H}=32.559$ & 0.000 \\
\hline \multicolumn{6}{|l|}{ Early adulthood (from 20 to 22 years) } \\
\hline Security & 5 & 5.17 & 5.5 & $\mathrm{H}=13.144$ & 0.001 \\
\hline Harmonious sexual relations & 5.33 & 5 & 6.17 & $\mathrm{H}=37.035$ & 0.000 \\
\hline Duty & 3.92 & 4 & 4 & $\mathrm{H}=2.185$ & 0.335 \\
\hline
\end{tabular}


Selection and peer-review under responsibility of the Organizing Committee of the conference

2672-8141

\begin{tabular}{|l|l|l|l|l|l|}
\hline Achievement of success & 5.83 & 5.5 & 6 & $\mathrm{H}=12.124$ & 0.002 \\
\hline Compensation for feeling of loneliness & 3.83 & 3.67 & 2.33 & $\mathrm{H}=38.680$ & 0.000 \\
\hline Personal independence ("escape from parents") & 5.5 & 5 & 5.67 & $\mathrm{H}=11.157$ & 0.004 \\
\hline Love & 5.67 & 6 & 6.83 & $\mathrm{H}=55.799$ & 0.000 \\
\hline Material welfare & 5.33 & 5.17 & 5.83 & $\mathrm{H}=14.425$ & 0.001 \\
\hline Revenge & 4 & 3.5 & 2.17 & $\mathrm{H}=43.493$ & 0.000 \\
\hline Communication with people & 5 & 5.17 & 5.5 & $\mathrm{H}=17.966$ & 0.000 \\
\hline Recognition by people around & 5.33 & 5.17 & 5.5 & $\mathrm{H}=6.462$ & 0.040 \\
\hline Parenthood & 4.67 & 4.83 & 5.17 & $\mathrm{~F}=8.077$ & 0.000 \\
\hline Self-actualization & 5.33 & 5.42 & 5.83 & $\mathrm{H}=13.461$ & 0.001 \\
\hline Happiness & 6 & 6.17 & 6.83 & $\mathrm{H}=30.060$ & 0.000 \\
\hline
\end{tabular}

From table. 06 it can be seen that the structure of valuable orientations determines the development of the reflexive component of family self-determination in adolescence more than in early adulthood. In adolescence students focused on the values of personal life are characterized by a positive self-attitude, self-confidence, internal locus of control, confidence in the ability to control their own life, the intensity of intrapersonal conflict in marriage and family relations, and the disintegration of the motivational and personal sphere. Students who are focused on the values of professional self-realization in their adolescence are characterized by self-confidence, ideas about themselves as a strong personality. In early adulthood students with a focus on the values of personal life show a positive self-attitude, the ability to manage their own destiny, freely making decisions and implementing them. But at the same time the intensity of intrapersonal conflict in marriage and family relations remains, as well as mismatch in the motivational and personal sphere. In early adulthood students focused on gnostic and aesthetic values tend to believe that a person is able to control and manage their life.

Table 06. Assessment of differences' reliability in indicators of the reflexive component of family selfdetermination depending on the structure of students' valuable orientations

\begin{tabular}{|c|c|c|c|c|c|}
\hline \multirow{2}{*}{$\begin{array}{l}\text { Structural and content characteristics of } \\
\text { family self-determination }\end{array}$} & \multicolumn{3}{|c|}{ Value of a median } & \multirow[b]{2}{*}{ 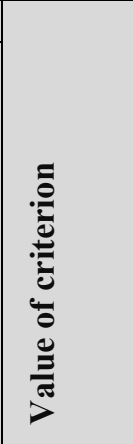 } & \multirow[b]{2}{*}{ 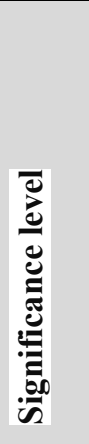 } \\
\hline & 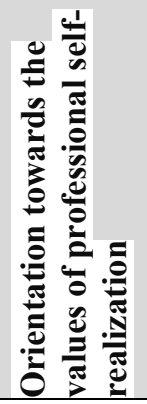 & 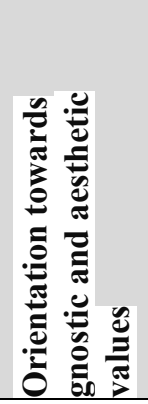 & 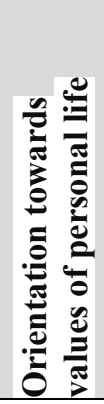 & & \\
\hline \multicolumn{6}{|c|}{ Adolescence (from 17 to 19 years) } \\
\hline I am an image & 5.33 & 5.25 & 5.67 & $\begin{array}{l}\mathrm{H}= \\
21.220\end{array}$ & 0.000 \\
\hline Self-confidence & 6 & 5 & 6 & $\begin{array}{l}\mathrm{H}= \\
28.540 \\
\end{array}$ & 0.000 \\
\hline Locus of control-I & 22 & 20 & 22 & $\begin{array}{l}\mathrm{H}= \\
17.879\end{array}$ & 0.000 \\
\hline Locus of control-life & 29 & 28 & 31 & $\begin{array}{l}\mathrm{H}= \\
12.452\end{array}$ & 0.002 \\
\hline $\begin{array}{l}\text { Intensity of intrapersonal conflict in the "happy } \\
\text { family life" sphere }\end{array}$ & 1 & 3 & 4 & $\begin{array}{l}\mathrm{H}= \\
54.414\end{array}$ & 0.000 \\
\hline
\end{tabular}




\begin{tabular}{|l|l|l|l|l|l|l|}
\hline $\begin{array}{l}\text { Index of mismatch, disintegration in the } \\
\text { motivational and personal sphere }\end{array}$ & 28 & 31.5 & 35 & $\mathrm{H}=8.918$ & 0.012 \\
\hline \multicolumn{5}{|c|}{ Early adulthood (from 20 to 22 years) } \\
\hline I am an image & 5.33 & 5.33 & 5.67 & $\mathrm{H}=7.157$ & 0.028 \\
\hline Self-confidence & 6 & 6 & 6.5 & $\mathrm{H}=4.994$ & 0.082 \\
\hline Locus of control-I & 22 & 22.5 & 23 & $\mathrm{H}=1.521$ & 0.467 \\
\hline Locus of control-life & 27 & 31 & 31 & $\begin{array}{l}\mathrm{H}= \\
14.049\end{array}$ & 0.001 \\
\hline $\begin{array}{l}\text { Intensity of intrapersonal conflict in the "happy } \\
\text { family life" sphere }\end{array}$ & 0.5 & 1 & 3 & $\begin{array}{l}\mathrm{H}= \\
36.851\end{array}$ & 0.000 \\
\hline $\begin{array}{l}\text { Index of mismatch, disintegration in the } \\
\text { motivational and personal sphere }\end{array}$ & 28 & 24 & 33 & $\begin{array}{l}\mathrm{H}= \\
13.363\end{array}$ & 0.001 \\
\hline
\end{tabular}

So, when analyzing the results of our empirical research we identified the features of family selfdetermination of students depending on the structure of valuable orientations in adolescence and early adulthood. Valuable orientations have an equal impact on the development of cognitive and motivational components of students' family self-determination. The structure of valuable orientations largely determines the features of the development of value-emotional, reflexive, and regulatory-behavioral components of family self-determination in adolescence compared to early adulthood. Therefore, adolescence is a sensitive period of influence of valuable orientations on the process of family selfdetermination of modern youth.

Thus, the initial hypothesis that the content and structural characteristics of family selfdetermination are due to the structure of valuable orientations and the age of the respondents was generally confirmed.

\section{Conclusion}

The conducted research aimed at studying the influence of valuable orientations on the formation of family self-determination in adolescence and early adulthood allows us to draw the following conclusions.

The results show that there are significant differences in the structure of valuable orientations of modern students. The majority of surveyed students are focused on the values of personal life (57 \%). Highsignificant values for them are a happy family life, love, health, and having good and loyal friends. The next group consisted of students focused on gnostic and aesthetic values (25.2\%). These respondents differ in the significance of such values as knowledge, creativity, beauty of nature and art. The third group included students focused on the values of professional self-realization (17.8\%). The importance of an active life, interesting work, financially secure life, self-confidence, freedom as independence in acts and actions distinguishes students of this group.

Students guided by the values of personal life are of high importance of family roles "I am a future husband / wife, I'm a future father /mother, I am a host / hostess, I am a son / daughter" so as in adolescence as in early adulthood. In adolescence the role of family values (parental family, marriage, my mother, my father, future family life), the positive perception of marriage and family relations (family in general, We are a family, the status of the individual within the family structure, attitude towards future marriage partner, themselves, future children, love of romantic type, joint family recreation and leisure activities, parental family and my mother), life orientation (purposes in life, process of life, effectiveness of life, 
https://doi.org/10.15405/epiceepsy.20111.3

Corresponding Author: Svetlana Vasilyevna Merzlyakova

Selection and peer-review under responsibility of the Organizing Committee of the conference

2672-8141

meaningfulness). In early adulthood, valuable orientations have less influence on the value-emotional component of students ' family self-determination. Family values remain important. A positive assessment of marriage and family relations is typical only for the following elements: family as a social institution, attitude towards future marriage partner, themselves, future children, and sex. In early adulthood students of this group are characterized by purposefulness, satisfaction with self-realization, and meaningfulness of life. In adolescence and early adulthood students are characterized by the value of present and future, the availability of a happy family life, and a negative attitude towards divorce. In adolescence students have a value of the past, a negative attitude towards family conflicts, and an attitude that a marriage partner will perform an emotional and psychotherapeutic function in the family. In early adulthood students become more accessible in the field of active life. The motivational component of family self-determination in adolescence and early adulthood is characterized by the significance of such marital motives as love, happiness, harmonious sexual relations, success, material welfare, self-actualization, personal independence, security, communication with people, recognition by people around, and parenthood. The reflexive component of family self-determination in adolescence and early adulthood is characterized by a positive self-attitude, a belief in the ability to control one's own life, the intensity of intrapersonal conflict in marriage and family relations, and the disintegration of the motivational and personal sphere. In adolescence students who are focused on the values of personal happiness also have self-confidence and an internal locus of control.

In a group of students focused on gnostic and aesthetic values, differences were found in the indicators of value-emotional, regulatory-behavioral, motivational, reflexive components of family selfdetermination. In adolescence and early adulthood students have positive attitudes towards their future marriage partner, themselves, future children, and sex. In adolescence students are also characterized by a positive perception of their own family (We are a family), parental family, image of their mother, position of an individual in the family structure, love of romantic type, family recreation and leisure. In early adulthood students have a positive dynamic in life-sense orientations: they increase their purposefulness. In adolescence students are characterized by the availability of knowledge and creative activity, a neutral attitude towards family conflicts and divorce. In early adulthood accessibility in such areas of life as a happy family life and creativity, a negative attitude towards divorce, and a pronounced attitude towards the fact that a marriage partner will perform parental and educational, emotional and psychotherapeutic functions in the family. In adolescence students who are focused on gnostic and aesthetic values are more likely to marry out of a sense of revenge (for a former lover or for the evil of their parents). In early adulthood students of this group tend to believe that a person is able to control and manage their lives.

Students who focus on the values of professional self-realization are characterized by the lowest indicators of the cognitive component (I am a future husband / wife, I am a future father / mother, I am a host / hostess, I am a son / daughter) of family self-determination in adolescence and early adulthood. In this group of students, the regulatory-behavioral component differs in adolescence in the availability of knowledge and a negative attitude towards family conflicts. In early adulthood students show an availability of an active life, but there is an extremely low availability of a happy family life. Students with a focus on the values of professional self-realization in adolescence have the following marital motives: personal independence, self-actualization, compensation for feelings of loneliness. In early adulthood such motives for marriage as revenge and compensation for feelings of loneliness are actualized. In adolescence the 
reflexive component of family self-determination of students in this cluster is characterized by selfconfidence, ideas about themselves as a strong personality.

\section{Acknowledgments}

The reported study was funded by RFBR, project number 20-013-00072.

\section{References}

Alekhin, A. N., Koroleva, N. N., \& Ostasheva, E. I. (2015). Semantic structures of world image as internal factors in self-destructive behaviour of today's teenagers. Psychology in Russia: State of the Ar, $8(1), 125-138$.

Arina, G. A., Iosifyan, M. A., \& Nikolaeva, V. V. (2018). Explicit and implicit values are associated with decision making in dilemmas related to health. National Psychological Journal, 4(32), 77-85. https://doi.org/10.11621/npj.2018.0407

Berberyan, A. S., \& Berberyan, E. S. (2017). Ethnopsychological aspects of life meaning and value orientations of students. Questions of Psychology, 1, 103-115.

Danilenko, O. I., Li, T., \& Xu, I. (2017). Values of contemporary Chinese and Russian students: a comparative analysis of priorities. Questions of Psychology, 3, 50-60.

Fantalova, E.B. (2001). Diagnostics and psychotherapy of internal conflict. Samara.

Garvanova, M., \& Papazova, E. (2017). Values Of Bulgarian Students In Emerging Adulthood: Dynamic Approach. European Proceedings of Social \& Behavioural Sciences, 264-270. https://doi.org/10.15405/epsbs.2017.10.25

Lebedeva, N. M., \& Tatarko, A. N. (2018). Basic values in Russia: their dynamics, ethno cultural differences, and relation to economic attitudes. Psychology in Russia: State of the Art, 11(3), 36-52.

Leontyev, D.A. (2000). Test of meaning-life orientations (MLO). Moscow.

Merzlyakova, S. V. (2019). Family self-determination of young people: structure and determinants: a monograph. Publishing House «Color».

Merzlyakova, S. V., Zhilkina, V. A., Zobnina, O. A., \& Sokova, N. A. (2018). Family Self-Determination Of Students In The Process Of Professionalization. The European Proceedings of Social \& Behavioural Sciences, LIII, 347-355. https://doi.org/10.15405/epsbs.2019.01.33

Podolskiy, A. I., \& Idobaeva, O. A (2019). Quo vadis? Trajectories of value-motivational development of modern Russian youth. Questions of Psychology, 2, 45 - 58.

Semenova, L. E., Serebryakova, T. A., \& Knyzeva, E. V. (2018). Pilot program for optimizing parenting motivation. National Psychological Journal, 1(29), 30-37. https://doi.org/10.11621/npj.2018.0103

Shorokhova, V. A., Khukhlaev, O. E., \& Dagbayeva, S. B. (2016).Relationship between Values and Religious Identity in Buddhist Adolescent. Cultural-Historical Psychology, 12(1), 66-76. https://doi.org/10.17759/chp.2016120107

Vartanova, I. I. (2014). The role of motivation and system of values in the development of upper secondary school pupils' personalities. Psychology in Russia: State of the Art, 7(2), 27-38.

Vartanova, I. I. (2016). The system of values, motivation and self-attitude: gender features in high school students. National Psychological Journal, 4(24), 115-121. https://doi.org/10.11621/npj.2016.0414

Volkova, A. N., \& Trapeznikova, T. M. (1985). Methodical Receptions of Diagnostics of Matrimonial Relations. Questions of psychology, 5, 110-116.

Zhuravleva, N. A. (2015). Businessmen value orientations dynamics in conditions of macrosocial changes. Psychological Journal, 36(1), 46-60. 